\title{
GOODS AND SERVICES TAX (GST) AND TRAINING FOR ITS IMPLEMENTATION IN INDIA: A PERSPECTIVE
}

\author{
B. Anbuthambi ${ }^{1}$ and N. Chandrasekaran ${ }^{2}$ \\ ${ }^{I}$ Department of Management Studies, Sri Chandrasekharendra Saraswathi Viswa Mahavidyalaya, India \\ ${ }^{2}$ Loyola Institute of Business Administration, India
}

\begin{abstract}
:
Government of India has passed GST Bill in 2016. It would be implemented from the second quarter of the financial year 2017-18. GST training must begin for personnel of the revenue department with Union and State Governments. Then only its effective implementation is possible. It is likely that the way they were administering the indirect tax regime would change. Training needs and perspective become important as not only the rate, submission forms but also the information technology system that they were using would also change. Similarly, GST would impact businesses as there would be changes in certain processes. Training must cover: supply chain network, marketing and pricing and accounting. AS GST is likely to impact from partnership firms, individual service providers, small, medium and micro firms and large industries, all of these firm representatives are to be trained. Thus, millions of such professionals need to be trained.
\end{abstract}

Keywords:

Economic Growth, Goods and Services Tax, Domestic and International markets, $O E C D$

\section{INTRODUCTION}

The Introduction of Goods and Services Tax (GST) [1] in India will be an important step in the field of indirect tax reforms in India. It would bring together a large number of Central Government and State Government taxes into a single tax. This allows the set-off in prior stage of the taxes. This could mitigate the effects due to cascading. Further, it provides the way for a common level national market for industries and Government in India. For the consumer level, the biggest gain would be in the areas of reduction in the tax burden on goods and services. Introduction of GST would make Indian products and services competitive. Competitiveness would improve in the domestic and international markets. Studies show that this would spur economic growth $[2,3]$.

Any fiscal intervention will need a lot of efforts from the government to put in place major changes. Fiscal intervention could be taxes - personal, corporate and wealth in case of direct taxes. And in case of indirect taxes, it may be excise, customs and sales tax. Others include: public expenditure like MNREGA programme for welfare of people; public debt and any of the direct fiscal incentives or disincentives as may be required in the economy from time to time. Some of the interventions will need imparting skills at departmental level. But, others may need large scale training as a part of change management. One such is the implementation of GST in India which would be requiring a major effort. This is because it touches all levels from government department to different business including a large number of small, medium and micro industries. GST Implementation being one of the large change management programmes requires stronger efforts. The Government especially Ministry of Finance is planning and willing to provide resources both time and money for implementing the training programmes on GST for various levels of officers in department level and other stakeholders. Here we have given some perspectives for one to understand the extent of effort required for successful change management.

\section{GST GLOBAL PERSPECTIVE}

Table.1. Comparison of different federal VAT systems across countries

\begin{tabular}{|c|c|c|}
\hline $\begin{array}{l}\text { Nature of } \\
\text { VAT }\end{array}$ & $\begin{array}{c}\text { Country } \\
\text { Examples }\end{array}$ & Disadvantages \\
\hline $\begin{array}{l}\text { Independent } \\
\text { VATs at } \\
\text { Centre and } \\
\text { Sates }\end{array}$ & $\begin{array}{l}\text { Brazil, } \\
\text { Russia, } \\
\text { Argentina }\end{array}$ & $\begin{array}{l}\text { Differences in base and rates } \\
\text { weaken Administration and } \\
\text { compliance. Inter-state } \\
\text { transactions difficult to manage }\end{array}$ \\
\hline $\begin{array}{l}\text { VAT levied } \\
\text { and } \\
\text { administered } \\
\text { at Centre }\end{array}$ & $\begin{array}{l}\text { Australia, } \\
\text { Germany, } \\
\text { Austria, } \\
\text { Switzerland, } \\
\text { etc. } \\
\end{array}$ & $\begin{array}{l}\text { State } \text { government relieved } \\
\text { of responsibility of raising } \\
\text { taxes which also takes away } \\
\text { fiscal discretion of States }\end{array}$ \\
\hline Dual VAT & $\begin{array}{l}\text { Canada and } \\
\text { India today }\end{array}$ & $\begin{array}{l}\text { A combination of the above } \\
\text { two and hence limits both } \\
\text { their disadvantages common } \\
\text { base and common or similar } \\
\text { rates }\end{array}$ \\
\hline $\begin{array}{l}\text { "Clean" } \\
\text { dual VAT }\end{array}$ & India's GST & $\begin{array}{l}\text { Facilitate administration and } \\
\text { compliance, including for inter- } \\
\text { state transactions, while } \\
\text { continuing to provide some } \\
\text { fiscal autonomy to the States. }\end{array}$ \\
\hline
\end{tabular}

Source: World Bank (2015); Adapted from: Vivek and Parchi Patil, A Treatise on Goods and Service Tax - NDA cornerstone on Taxation [10].

GST is a unified Tax system in most of the countries. About 165 countries have already implemented GST at national level. Canada and Brazil only have dual GST. The standard rate of most of the countries ranges from 16 to 20 per cent. The Table. 1 gives structure of GST/VAT across the countries [10].

It may be also noted that different countries have implemented GST over many years. France was one of the oldest having implemented in 1954 itself. Similarly, an advanced nation like United States of America has not figured in the list. While countries like France and United Kingdom have a standard rate of 20 per cent, Malaysia has as low as 6 per cent. The Table. 2 GST 
- Global Scenario below gives year of implementation and standard rates at some of the leading countries.

Table.2. GST - Global Scenario

\begin{tabular}{|c|c|c|}
\hline Country & Year of Implementation & Standard rate \\
\hline France & April, 1954 & $20 \%$ \\
\hline United Kingdom & April, 1973 & $20 \%$ \\
\hline South Korea & 1977 & $10 \%$ \\
\hline Japan & April, 1989 & $\begin{array}{c}8 \% \text { (to be raised to } \\
10 \% \text { in 2017) }\end{array}$ \\
\hline Singapore & April, 1994 & $7 \%$ \\
\hline Australia & July, 2000 & $10 \%$ \\
\hline Malaysia & April, 2015 & $6 \%$ \\
\hline
\end{tabular}

Source: GST-Global Scenario [6]

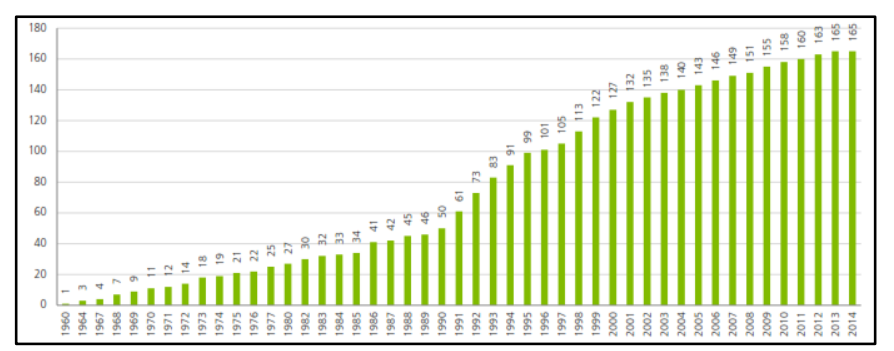

Source: OECD report on countries with VAT 1960-2014

Fig.1. Increase in the VAT/GST Geographies

In this we may see a significant shift happening between 1990 and 1994. There has been a gradual increase since then. From the graph it looks like India has taken adequate time to evaluate the complexity of implementing in a vast and heterogeneous geography. This itself would give enough responsibility to ensure that implementation is successful and without any hiccups.

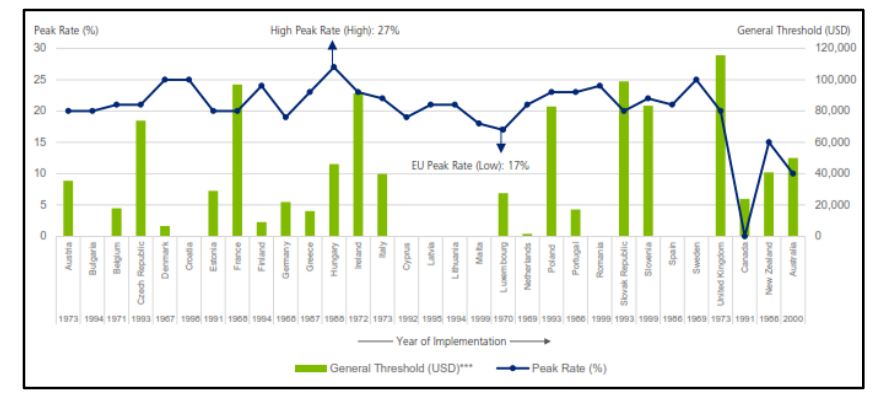

Source: OECD and European Commission report on VAT/GST rates and threshold applicable in member countries

Fig.2. VAT/GST rates and threshold limit - 2015

Another important aspect which one will have to understand while discussing on implementation of GST is: the rate and general threshold level above which it must be valid. These two parameters will impact the number of establishments and service providers. It may be useful to understand better the extent to which it impacts the ultimate consumers [4]. Further, the stakeholders must understand GST in right perspective. Else, it could be difficult to carry on the government intent and facilitate smooth implementation of the fiscal change management process.
It may be observed that country like Hungary which has a peak rate of 30 per cent has threshold level of USD 50,000 for effective level of compliance. But, countries like France and United Kingdom has 20 per cent as rate but starts at a higher compliance level. Some countries have low rates and lower compliance level as well. It is concluded that the rate and compliance even among OECD countries are driven by country specific macro-economic conditions. These have been confirmed by OECD studies which are mentioned in the references as well $[7,8]$.

\section{GST IN INDIA}

A brief historical perspective on progress of GST in India is given below:

- In 1994, Amaresh Bagchi Report suggested that Value added tax may be implemented in India which would be a prelude to GST. Ahim Dasgupta empowered committee appointed in 2000 implemented VAT in 2005 replacing the old tax system. This had a good transition.

- Vijay Kelkar Task Force set up in 2004 recommended implementation of GST and suggested integration of indirect taxes. Based on recommendations of various committees and high level discussion, the Union Government in its budget 2006-07 announced that the GST would be implemented with effect from April 09, 2010.

- The Union government along with State Governments finance minister or nominee started to study the impact of GST on the revenue of each of the states. The idea was to ensure smooth transition into GST regime. Task Force of Finance Ministers submitted their report in 2009 on structure of GST in India. Yet the Union Government could not put in place as there was no consensus on rate structure. Further, there were many other political developments and priorities which pushed GST into the back burner.

- Constitution, 115th Amendment bill was introduced on March 22, 2011. And the same was referred to Parliamentary Standing Committee on Finance for discussion. 115th Amendment Bill lapsed in 2004. Further, 122nd Amendment Bill to Constitution was introduced on December 19th 2014. The Lok Sabha passed the Bill on May 6th 2015 and Rajya Sabha passed the same on August 3rd 2016. The Government is targeting to put in place with effect from July 1, 2017.

\section{GST MODEL}

India would have a dual rate structure. There would be a central GST and State GST. As there would be the inter-state movement of Goods and Services, there would be an inter-state transfer mechanism. GST happens at place of consumption unlike sales tax which is at place of origin / manufacture. Hence change management becomes important.

The GST replaces the taxes currently levied, which is collected by central Government. This includes Central Excise duty, Duties of Excise (Medicinal and Toilet Preparations), Additional Duties of Excise (Goods of Special Importance), Additional Duties of Excise (Textiles and Textile Products), Additional Duties of Customs (commonly known as CVD), 
Special Additional Duty of Customs (SAD), Service Tax, Central Surcharges and Cesses so far as they relate to supply of goods and services [11].

The State taxes is subsumed using GST include State VAT, Central Sales Tax, Luxury Tax, Entry Tax (all forms), Entertainment and Amusement Tax (except when levied by the local, bodies), Taxes on advertisements, Purchase Tax, Taxes on lotteries, betting and gambling, State Surcharges and Cesses [11].

The 13th Finance commission task force suggested Central GST at $5 \%$ and State at $12 \%$ and combined $12 \%$. Sub-panel empowered committee recommended Central at $12.77 \%$; State $13.91 \%$ and combined at $26.68 \%$, Select committee of Rajya Sabha suggested that it must capped at $20 \%$. The final details of rate structure are still expected as a working committee again with State Government Finance Ministers is finalizing the same. In principle, the rate structure is clear where there would be Central GST; State GST and an inter-state GST for sharing of revenue from inter-state transaction so that the producing and consuming states are able to fairly split up. These are required as manufacturing resource base were set up on resource and skill availability and also on various fiscal support provided by the State governments.

Table.3. Nature of GST in India

\begin{tabular}{|c|c|c|}
\hline \multicolumn{3}{|c|}{ Dual GST } \\
\hline \multicolumn{2}{|c|}{ Transactions within the State } & $\begin{array}{c}\text { Interstate } \\
\text { Transactions }\end{array}$ \\
\hline SGST & CGST & IGST \\
\hline Levied by State & $\begin{array}{c}\text { Cevied by } \\
\text { Centre }\end{array}$ & Levied by Centre \\
\hline $\begin{array}{c}\text { Implemented } \\
\text { through Multiple } \\
\text { Statues }\end{array}$ & $\begin{array}{c}\text { Implemented } \\
\text { through Single } \\
\text { Statue }\end{array}$ & $\begin{array}{c}\text { Implemented through } \\
\text { Single Statue }\end{array}$ \\
\hline $\begin{array}{c}\text { Paid to the } \\
\text { account of State } \\
\text { Govt. }\end{array}$ & $\begin{array}{c}\text { Paid to the } \\
\text { account of } \\
\text { Central Govt. }\end{array}$ & $\begin{array}{c}\text { Paid to the account of } \\
\text { Central Govt. }\end{array}$ \\
\hline & IGST = CGST+SGST \\
\hline & $\begin{array}{c}\text { Addl. Levy @ 1\% on } \\
\text { goods for a period of } \\
2 \text { years }\end{array}$ \\
\hline
\end{tabular}

Source: Goods and Service Tax (GST) in India-Challenges Ahead [9]

The Table. 3 provides a brief nature of GST that would be implemented in India.

Key features of the 122nd Amendment Bill introduced in Lok Sabha on 2014 include: Concurrent jurisdiction for levy of GST by the Centre and the States - proposed Article 246A; authority for Centre to levy and collect of IGST on supplies in the course of inter-state trade or commerce including imports proposed Article 269A; authority for Centre to levy non vatable Additional Tax - to be retained by originating State and GST defined as any tax on supply of goods or services or both other than on alcohol for human consumption - proposed Article 366 (12A).

\section{NEED FOR TRAINING}

The tax revenue department has huge responsibility of making smooth transition. The revenue department will have train a large number of its officers and field staff for enabling the same. The National Academy of Customs, Excise and Narcotics (NACEN) has been tasked with the mammoth task of training officials of both the Centre and States. According to one report, the target is to train 60,000 officers. This is from administration side [5].

There is another angle to GST which is towards the parties on whom incidence and impact are there. One may have to understand the need of stakeholders like government, business and supply chain network partners. The impact of GST on business would be as shown below:

- Business processes could change as the collection would be at the point of consumption and not at manufacture or service point. Most of the times, service point and physical service are normally same. But, there could be issues wherever virtual service is involved. Further, service is delivered through third parties like computer hardware, software and so on build complexity. This would need process definition and training all stakeholders.

- Accounting related changes would happen. Hence software as well as accountants needs to be trained for implementing such changes. The object is to ensure minimal errors.

- As mentioned above, changes in IT systems would be required. This would involve many of the applications at the firm level; at the department level and interface of both. The operating resources need to be abreast about the rule and ensure synchronized financial flow is established.

- Marketing department must also understand the price impact. Hence, it needs to update in finalizing the price structure and sell the products and services at different regions.

- Supply chain network structure would significantly change in the post GST era. GST may not create any need for creating transfer points for optimal sales tax structure. There can be fewer hubs and flow of goods need to be handled than what is being done currently. Consolidation would need setting up of large distribution centres and multi user facilities. These need better evaluation and understanding of supply chain decisions. Hence this domain requires phenomenal training efforts.

- Cash flow management may also change with the shift in incidence. And accounts department must familiarize with the same. And they need to be trained towards the same.

- Fiscal administration would change forms and filling required. Firms and business service providers need to register for GST and follow a new set of fillings.

Thus, there is going to be a need for training at many levels, which is from operators to decision makers in different domains. Everyone from individual service providers, small, medium and large firms have to adopt GST from the second quarter of the financial year 2017-18. This shows need for training millions of professionals. Unless different stakeholders rise up to the need for delivering the same, the transition could be difficult. 


\section{RECOMMENDATIONS}

Government as it has provided in its plan use their machinery. It must engage outsourced partners to deliver training programmes to their departmental staff in both Central and State Governments. The selection of trainers must be through a rigorous delivery partners. Then there must be a standardized training mechanism and evaluation process so that all trainees are on near equal or equal footing to deliver value. Course content, delivery and testing are all equally important and continuous validation is critical component of the training.

Government must find ways of developing open source content for those who may like to have self-learning mechanism and for supplementary learning after completion of the training provided by the department. The type of content, scope for selflearning and pedagogy must be clearly captured. It is important that the content engages different level of stakeholders and appropriately drives them to respective levels and role in learning GST rules and procedures.

Government must provide during the initial phase $24 \times 7$ help desk for trainers and trainees on GST rules and regulations. This is an essential requirement. But delivering this has huge challenges as levels and stakeholders requirement vary widely. Second, country like India with vast language and cultural variations require training material in different linguistics and based on learning aptitude. While a few regions may like easy learning tools, others may not mind rigorous and hard learning material as well in terms of complexity involved. Further, setting up audio - visuals must also take this factor into consideration.

Training by distributed delivery mechanism of encouraging private parties, professional bodies and NGOs should also be encouraged. Lastly, training for high order managerial decisions like network redesign, pricing analysis and financials must be done by qualified professionals. Government must encourage professional bodies and management institutions to deliver the same. There must be some sops for them to do the same.

\section{CONCLUSION}

The implementation of GST will play an important role in the growth of India Economy. The implementation of a comprehensive GST will pave way to efficient allocation of factors of production and will lead to gain in GDP, exports and the growth of the economy.

As there are so many benefits, appropriate implementation is important. GST Training plays a crucial role in the implementation of GST. There is a number of stakeholders in both central and state level, who are to be trained. Training tax department level employees is important. It is spread across the country. Hence huge efforts are required by the executing agencies. Similarly, accounts, marketing and supply chain managers of firms are to be trained. This has to done by government agencies and third party trainers. Another important GST related training is in functional areas. This would be redesign of supply network because of GST. The challenges and opportunities of GST training are contextual like that of Y2K for IT firms.

\section{REFERENCES}

[1] History of GST, Historical Background of GST, Available at: https://gst.caknowledge.in/historical-background-gst/

[2] GST and Economic Growths, Available at: http://www.lawcrux.com/data5t/gt/gtartl/gst_economic_gro wth.htm

[3] GST, Available at: http://www.gstindia.com

[4] Moving to Goods and Services Tax in India: Impact on India's Growth and International Trade, Available at: http://www.ncaer.org/publication_details.php?pID=30

[5] GST Training: Govt Faces Steep Climb as Deadline Nears, Available at: http://indianexpress.com/article/india/indianews-india/gst-training-govt-faces-steep-climb-asdeadline-nears-3061001/

[6] GST-Global Scenario, Available at: http://www.moneycontrol.com/news/business/economy/ind ia-joins-global-league-heres-the-list-of-gst-rates-across-theworld-2283941.html

[7] Alain Charlet and Stephane Buyden, "The OECD International VAT/GST Guidelines: Past and Future Developments", International Vat Policy Developments, Vol. 1, No. 2, pp. 175-184, 2012.

[8] Alain Charlet and Jeffrey Owens, "An International Perspective on VAT”, Tax Notes International, Vol. 59, No. 12, pp. 943-954, 2010.

[9] Goods and Service Tax (GST) In India-Challenges Ahead, Available at: https://www.icsi.edu/portals/70/GST\%20ICSI\%20(28\%2002.pdf

[10] Vivek and Parchi Patil, "A Treatise on Goods and Service Tax - NDA cornerstone on Taxation", Available at: http://www.gstindia.com/gst-is-going-to-end-our-tax-woes.

[11] An overview of GST, Available at: http://pib.nic.in/newsite/PrintRelease.aspx?relid=161273. 